\title{
Drip Fertigation in Vegetable Crops for Enhancing Productivity and Resource Use Efficiency: An Overview
}

\author{
R. Sathya Priya*, C. Chinnusamy, R. Karthikeyan and R. Kuttimani \\ Directorate of Crop Management, Tamil Nadu Agricultural University, \\ Coimbatore - 641 003, Tamil Nadu, India \\ *Corresponding author
}

\section{A B S T R A C T}

Vegetables are important constituents of Indian agriculture and nutritional security due to their short duration, high yield, nutritional richness, economic viability and ability to generate on-farm and off-farm employment. Today, India is the second largest producer of the vegetables $(90.8 \mathrm{Mt})$ in the world, contributing 14.45 per cent of the total world production. Micro-irrigation is introduced primarily to save water and increase the water use efficiency in agriculture. It has created interest because of decreased water requirement and possible increase in production. The system has proved its superiority over other

\section{Keywords}

Drip fertigation,

Vegetable crops,

Productivity, Resource use efficiency.

\section{Article Info}

Accepted:

24 September 2017

Available Online:

10 November 2017 conventional method of irrigation. It also has the potential to increase the yield of crops even at reduced irrigation water application. The concept of Horticulture is shifting from maximizing yield to maximizing value with water management assumes paramount importance to reduce the wastage of water to increase the water use efficiency. The need of the hour is therefore, maximising the production per unit drop of water. Hence in the present day context, lot of emphasis is being given in improving the irrigation practices to increase the vegetable production and to sustain the productivity levels. Drip fertigation with water soluble fertilizer improved the root system by inducing effect on the root architecture especially in the production of highly fibrous root system. Reduction in water consumption due to drip method of irrigation over the surface method of irrigation varies from 30 to 70 per cent and productivity gain in the range of 20 to 80 per cent for different vegetable crops. Fertigation is the technique of supplying dissolved fertilizer to crops through an irrigation system. Small applications of soluble nutrients saves labour, reduces compaction in the field, thereby enhancing productivity. Fertigation allows nutrient placement directly into the plant root zone during critical periods in the required dose. By introducing drip fertigation, it is possible to increase the yield potential of vegetable crops by three fold with the same quantity of water. All these emphasize the need for water conservation, improvement in productivity and resource use efficiency to achieve in vegetable crops.

\section{Introduction}

India is the brick of a Golden Revolution in Horticulture with a total annual production of 149 Million tonnes. Vegetables are important constituents of Indian agriculture and nutritional security due to their short duration, high yield, nutritional richness, economic viability and ability to generate on-farm and off-farm employment. Our country is blessed with diverse agro-climates with distinct seasons, making it possible to grow wide 
array of vegetables. Today, India is the second largest producer of the vegetables (90.8 Million tonnes) in the world, contributing 14.45 per cent of the total world production. Moisture is maintained in the medium through application of water at critical stage of crop. There is urgent need to reduce the consumption of water in irrigation by developing new technologies and methods that could help to utilize precious input in an effective way. Fertigation is such innovative technology of applying water soluble fertilizers through drip irrigation. Drip irrigation is with 90 per cent irrigation efficiency. This method increases the crop yield in general to the tune of 25 to 30 per cent with saving of irrigation water to the extent of 50 to 60 per cent, when compared to conventional irrigation method (Yadav et al., 1993). The fertigation allows application of right amounts of plant nutrients uniformly to the wetted root volume zone where most of the active roots are concentrated and this helps enhance nutrient use efficiency. It has been found to improve the productivity and quality of crop produce along with improved resource use efficiency (Jat et al., 2011). Fertigation saves fertilizers up to 25 per cent (Vaishnava et al., 1995), thus fertigation results in appropriate and efficient use of precious commodities such as water and fertilizer. As the water soluble fertilizers are very costly inputs, therefore the efforts are made by various researchers to reduce the quantity of water soluble fertilizers (nitrogen and potassium) in conjunction with straight fertilizer (single super phosphate) to enhance the yield potential of vegetable crops and fertilizer use efficiency. The main point which considered is that changing from single product to creating value added product through a balanced, crop specific plant nutrition concept. The crop competence for nutrients will become more and more crucial, but even more relevant to transmit the superior knowledge to the end user is essential. Thus, fertigation is an important concept and the key focus of this article is on assisting the horticulturist in general and vegetable crops in particular.

\section{What is fertigation?}

The practice of supplying crops in the field with fertilizers via the irrigation water is called fertigation. In fertigation, timing, amounts and concentration of fertilizers applied are easily controlled. Fertigation allows the landscape to absorb upto $90 \%$ of the applied nutrients, while granular or dry fertilizer application typically results in absorption rates of 10 to $40 \%$ (Table 1). Fertigation ensures saving in fertilizer (40$60 \%$ ), due to "better fertilizer use efficiency" and "reduction in leaching" (Kumar and Singh, 2002). Drip irrigation is often preferred over other irrigation methods because of the high water application efficiency on account of reduced losses, surface evaporation and deep percolation. Because of high frequency water application, concentrations of salts remain manageable in the rooting zone. The regulated supplies of water through drippers not only affect the plant root and shoot growth but also the fertilizer use efficiency. Fertigation through drip irrigation reduces the wastage of water and chemical fertilizers, optimizes the nutrient use by applying them at critical stages and at proper place and time, which finally increase water and nutrient use efficiency. Moreover, it is well recognized as the most effective and convenient means of maintaining optimal nutrient level and water supply according to crop development stage, specific needs of each crop and type of soil.

\section{Fertilizer used in fertigation}

Urea, potash and highly water soluble fertilizers are available for applying through fertigation. 
Application of super phosphorus through fertigation must be avoided as it makes precipitation of phosphate salts. Thus phosphoric acid is more suitable for fertigation as it is available in liquid form.

Special fertilisers like mono ammonium phosphate (nitrogen and phosphorus), poly feed (nitrogen, phosphorus and potassium), Multi K (nitrogen and potassium), Potassium sulphate (potassium and sulphur) are highly suitable for fertigation0 as they are highly soluble in water. $\mathrm{Fe}, \mathrm{Mn}, \mathrm{Zn}, \mathrm{Cu}, \mathrm{B}, \mathrm{Mo}$ are also supplied along with special fertilisers (Tables 2 and 3).

\section{Hypotheses for fertigation techniques}

Fertigation enhances fertilizer use efficiency by $40-60 \%$, hence recommended doses of fertilizers may be reduced proportionally.

Drip irrigation promotes root growth in surface layer (about 70-80\%), hence the nutrients from sub-surface layers may not be extracted.

Drip irrigation leads to moisture content around above field capacity hence may promote leaching of nutrients.

Use of water soluble fertilizers (WSF) may lead to leaching losses beyond surface layer, hence frequent split application of WSF is desirable.

The frequency of fertigation may increase with fertilizers doses in order to avoid leaching losses or toxicity if any.

\section{Need of fertigation}

Rapid increase in area under micro irrigation, now fertigation is getting momentum in number of the countries. The concept of fertigation is new to the Indian subcontinent growing popularity to accept of this concept making it easy to adopt 'Fertigation'. Fertigation is the technique to apply water soluble solids or liquid fertilizers through the drip irrigation on weekly or monthly basis so as to reach each and every plant regularly and uniformly. It is the most effective and convenient means of maintaining optimum fertility level and water supply according to the specific requirement (Shirgure, 2000).

Fertigation permits application of a nutrient directly at the site of a high concentration of active roots and as needed by the crop. Scheduling fertilizer applications on the basis of need offers the possibility of reducing nutrient element losses associated with conventional application. Methods that depend on the soil as a reservoir of nutrients thereby increasing nutrient use efficiency.

Fertilizer savings through fertigation can be to the tune of 25-50 per cent (Haynes, 1985). Fertilizers and pesticides applied through a drip irrigation system can improve efficiency, save labour and increase flexibility in scheduling of applications to fit crop needs (Rolston et al., 1979).

However, all chemicals must meet the following criteria for the successful maintenance of the drip irrigation system (Bucks and Nakayama, 1980). However, increasing water scarcity and value crops and green houses to ensure higher escalating fertilizer prices may lead to greater efficiency of the two most critical inputs in crop adoption of the technology especially in high production. We should be conscious about that "per drop more crop".

\section{Fertigation scheduling}

Fertigation is the technique of supplying dissolved fertilizer to crops through an irrigation system. Small applications of 
soluble nutrients saves labour, reduces compaction in the field, thereby enhancing productivity. Fertigation allows nutrient placement directly into the plant root zone during critical periods in the required dose (Singandhupe et al., 2003; Jat, et al., 2011). Application of high dose of fertilizers not only causes economic loss but also leads to chemical changes in the soil and reduces the yield. Fertilizer requirement can be reduced by $15-25$ per cent with fertigation through drip without affecting the yield (Hongal and Nooli, 2007). Factors that affect fertigation module are soil type, available NPK status, organic carbon, soil $\mathrm{pH}$, soil moisture at field capacity, available water capacity range, aggregate size distribution, crop type and its physiological growth stages, discharge variation and uniformity coefficient of installed drip irrigation system.

The efficient fertigation schedule needs following considerations viz.

Crop and site specific nutrient management,

Timing nutrient delivery to meet crop needs and

Controlling irrigation to minimize leaching of soluble nutrient below the effective root zone.

In many situations, a small percentage of $\mathrm{N}$ and $\mathrm{K}(20-30 \%)$ and most or all $\mathrm{P}$ is applied in a pre-plant broadcast or banded application especially in the areas where either initial soil levels are low or early season irrigation is not required. Pre plant application of $\mathrm{P}$ is common since soluble P sources (phosphoric acid) are costlier than granular forms, to avoid the chemical precipitation in drip line and the movement of drip applied $\mathrm{P}$ away from the injection point is goverened by soil texture and soil $\mathrm{pH}$. Movement of $\mathrm{P}$ is particularly restricted in fine textured and alkaline soil. When making a pre-plant application of any nutrient, it is important that the fertilizer be placed within the wet zone of the drip system. A crop specific fertigation schedule can be developed using growing degree days implementation. A soil with high $\mathrm{N}$ supply capacity may require substantially low $\mathrm{N}$ fertilizers. Application of $\mathrm{N}$ and $\mathrm{K}$ in excess of crop requirement can have adhesive effect such as ground water contamination with nitrate $\mathrm{N}$, appearance of blossomend rot in tomato or pepper with heavy ammonical $\mathrm{N}$ application, reduction in specific gravity of potato and size of straw berry fruit with excessive $\mathrm{K}$ fertilization. Nutrient can be injected daily or bimonthly depending upon system design, soil type and farmer's preference. Frequent injection may be needed for sandy soil with poor water and nutrient capacity and grower who want to reduce injection pump size and cost. Since leaching is possible with drip irrigation, nutrient applied in any irrigation must not be subjected to excessive irrigation during that application or in subsequent irrigations.

It is possible to irrigate nutrient in noncontinuous (bulk) or continuous (concentration) way. Fertilizer should be injected in a period such that enough time remains to permit complete flushing of the system without over irrigation. Water that moves below the active crop root zone carry nitrate $\mathrm{N}$ or $\mathrm{K}$ in substantial quantities. One $\mathrm{cm}$ of leachate at $100 \mathrm{mg}$ nitrate $\mathrm{N}$ per litre would contain $10 \mathrm{~kg} \mathrm{~N}$ per ha.

Drip irrigation introduces possibilities for precise application of fertilizer and other chemicals. The restricted root growth necessitates the type of fertilizer application "fertigation", which prevents nutrient deficiencies. The high efficiency of water application reached in drip irrigation systems is ideal for the high efficiency of applied nutrients in fertigation. But, some of these potential benefits can reverse into disadvantages when the irrigation system design or management is not correct (non- 
uniform nutrient distribution, over fertigation, excessive leaching, clogging).

\section{Crop response to fertigation in vegetable crops}

\section{Cauliflower and cabbage}

Fertigation of cauliflower with 100 per cent $\mathrm{RD}$ of $\mathrm{N}$ and $\mathrm{K}$ at every week upto 60 DAT and phosphorus as basal application registered significantly yield attributing characters then rest of the treatments. However, this treatment effect is at par with fertigation at 75 per cent of RD $\mathrm{N}$ and $\mathrm{K}$ at every week upto 60 DAT and phosphorus as basal application in case of yield. At higher fertigation level, crop meet out its nutritional requirement at respective growth stage which lead to luxurious growth and thereby enhancement of yield. Similar results were reported by Batsod (2007), Chetan and Singh (2009), Imtiyaz et al., (2009) and Bozkurt et al., (2011).

The yields of cauliflower were maximum at 100 per cent of recommended nitrogen dose through fertigation (Chetan and Singh, 2011). Kapoor et al., (2014) showed that increase in NPK fertigation level from 33.3 to 100 per cent RDF significantly increased number of leaves, relative leaf water content, marketable yield of cauliflower and benefit cost ratio but decrease in fertilizer expense efficiency. Drip based irrigation along with fertigation in general had higher fruit yield but lower benefit cost ratio in comparison to flood and conventional fertilizer application. Fertigation using water soluble fertilizers increased marketable yield in cauliflower by 21.3 per cent as compared to conventional application of fertilizers. Shinde et al., (2006) shows that fertigation with 125 per cent of the recommended rates of NPK fertilizer resulted in higher weight of head cabbage than 150 and 100 per cent recommended dose.

\section{Broccoli}

Singh et al., (2002) reported 115.37 and 17.32 per cent increase in broccoli yield with fertigation over drip irrigation and check basin method, respectively. Selim et al., (2012) reported that application of humic substances through fertigation increased total marketable yield and head diameter of broccoli as well as quality parameters (i.e., total soluble solids, protein and vitamin C). Higher nutrient concentrations were found in the broccoli heads and concentrations of plant available nutrients in soil after harvesting were also higher, indicating an improvement in soil fertility. Humic substances fertigation can be judged as an interesting option to improve soil water and nutrient status leading to better plant growth. Fertigation using water soluble fertilizers increased marketable yield in broccoli by 21.4 per cent as compared to conventional application of fertilizers. However, when 25 per cent nutrients were applied as basal through conventional fertilizer and 75 per cent nutrient through fertigation using water soluble fertilizers increase in marketable yield in broccoli was 12.3 per cent as compared to conventional application of fertilizer.

\section{Radish}

Shedeed et al., (2009) reported that significant increase in growth parameters of radish (plant height, LAI, fruit dry weight, total dry weight), yield components (number of fruits/plant, mean fruit weight, fruit yield/plant) and total fruit yield was observed with the application of 100 per cent RDF through fertigation over furrow and drip irrigation and soil application of fertilizers. The increased yield under fertigation might have resulted due to better water utilization (Manfrinato, 1971), higher uptake of nutrients (Bafna et al., 1993) and excellent soil-waterair relationship with higher oxygen 
concentration in the root zone (Gornat et al., 1973). Manfrinato (1971) recorded the benefit cost (B: C) ratio of Rs. 3.30 under 100 per cent RDF applied through water soluble fertilizers in fertigation as against Rs. 2.78 in 100 per cent RDF with conventional fertilizer application and surface irrigation.

\section{Brinjal}

Papadopoulos and Ristimäki Leena (2000) reported that fertigation irrespective of the combination of fertilizers has been found superior to the soil application of fertilizers. With only 50 per cent of recommended $\mathrm{N}$ through fertigation, higher yield of tomato and eggplant was obtained compared to application of full amount of $\mathrm{N}$ through conventional method, suggesting that $\mathrm{N}$ is more efficiently utilized when applied with the irrigation water. Tu et al., (2000) in a four year (1998-2001) investigation carried out in south-western Ontario, USA found that (a) drip irrigation and fertigation significantly increased tomato yield over the non-treated control (b) percentage of tomato fruit with blossom-end rot was reduced significantly to the negligible level in the drip-irrigated and fertigated treatments and (c) drip-fertigation provided significant yield advantage over drip-irrigation only in the year when rainfall was below normal during the periods of flowering, fruit set and fruit growth.

In brinjal, highest fruit yield of $42.33 \mathrm{t} \mathrm{ha}^{-1}$ was recorded in drip irrigation at 75 per cent of recommended $\mathrm{N}$ and $\mathrm{K}$ with maximum shoot length and number of branches per plant when compared to other levels of irrigation and fertigation (Vijayakumar et al., 2010). When different irrigation levels and nitrogen application levels were compared in brinjal, the highest yield (which was 23 per cent higher) was obtained at 75 per cent of surface irrigation and $120 \mathrm{~kg}$ nitrogen per hectare with the saving of 25 per cent water and $30 \mathrm{~kg}$
$\mathrm{N} \mathrm{ha}{ }^{-1}$ as compared with the maximum yield obtained in furrow irrigation (Aujla et al., 2007). When 25 per cent nutrients were applied as basal through conventional fertilizer and 75 per cent nutrient through fertigation using water soluble fertilizers increase in marketable yield in brinjal was 15.4 per cent as compared to conventional application of fertilizer.

\section{Tomato}

Fruit yield of 45.7 tha $^{-1}$ was obtained for tomato with application of recommended dose of fertilizers using polyfeed (19:19:19), MAP (12:60:0) and urea through fertigation, which was 22-27 per cnt higher compared to the crop which was provided with ordinary fertilizers through soil application (Prabhakar and Hebbar, 1996). The highest tomato yield in drip is possible because water and fertilizers are applied in a gradual and uniform form directly to the roots, in sync with the crop demand, without wetting the plants (Hartz and Bottoms, 2009; Shedeed et al., 2009; Marouelli et al., 2011a). However, for a greater economic feasibility of the system, it is important to manage the entire production system properly, especially for irrigation and fertigation (Zhang et al., 2010). Tomato plants properly drip irrigated and fertigated by drip systems become more vigorous and productive, which requires a greater extraction of soil nutrients (Hartz and Bottoms, 2009). However, as only part of the land is wet, a reduction in the volume of soil explored by the roots occurs (Marouelli et al., $2011 b)$. Thus, it is necessary to reevaluate the pre-established fertilization practices to maintain adequate fertility in the root zone (Hartz and Bottoms, 2009). Shedeed et al., (2009) and Zhang et al., (2010) reported that the amount of nutrients required by a particular crop may be quite variable depending on its productive potential and the climatic and soil conditions. Hebbar et al., 
(2004) showed that fertigation with $100 \%$ water soluble fertilizers (WSF) increased the tomato fruit yield significantly over furrow irrigated control and drip irrigation. The fertigation schedule was developed for protected conditions in tomato and a B.C ratio of 5.4 was obtained.

\section{Potato}

Darwish et al., (2003) studied the impact of $\mathrm{N}$ fertigation in potato and reported that fertigation with continuous $\mathrm{N}$ feeding through drip system based on actual $\mathrm{N}$ demand and available $\mathrm{N}$ in the soil resulted in 55 per cent $\mathrm{N}$ recovery; and for spring potato crop in this treatment, 44.8 per cent $\mathrm{N}$ need was met from the soil $\mathrm{N}$ and 21.8 per cent from the irrigation water. Higher $\mathrm{N}$ input increased not only the $\mathrm{N}$ derived from fertilizers, but also the residual soil $\mathrm{N}$.

\section{Chilli}

Darwish et al., (2003) reported that irrigation at 100 per cent $\mathrm{PE}+$ fertigation with 100 per cent $\mathrm{N}$ and $\mathrm{K}$ and 50 per cent $\mathrm{PE}+$ fertigation with 100 per cent $\mathrm{N}$ and $\mathrm{K}$ being at par recorded 67.06 and 65.78 per cent, respectively higher pod yield of chilli as compared to surface irrigation at 0.90 IW/CPE ratio + entire NPK as soil application. However, fertigation of 125 per cent of $\mathrm{N}$ and $\mathrm{K}$ led to marginal decrease in chilli pod yield over fertigation of 100 per cent of $\mathrm{N}$ and $\mathrm{K}$. Fertigation of 75 per cent, 100 per cent and 125 per cent $\mathrm{N}$ and $\mathrm{K}$ registered 50.6, 66.8 and 58.6 per cent increase in pod yield, respectively over soil application of $100 \% \mathrm{~N}$ and $\mathrm{K}+$ surface irrigation. Hence, irrespective of the fertilizer dose, there was marked increase in pod yield under fertigation. Similarly, Muralikrishnasamy et al., (2006) found B: C ratio of Rs. 1.87 with drip irrigation at 75 per cent $\mathrm{PE}+100$ per cent $\mathrm{N}$ and $\mathrm{K}$ through fertigation over Rs. 1.77 with surface irrigation at $0.90 \mathrm{IW} / \mathrm{CPE}$ ratio + entire NPK as soil application in chilli.

The number of fruits per plant was higher in high fertility area compared to the low fertility area. The highest number of fruits obtained for low fertility area was (119.33) under site specific drip fertigation providing daily drip irrigation, which was closer to that for site specific drip fertigation and recommended dose drip fertigation with daily drip irrigation (119.20 and 119.23, respectively) under high fertility area. Number of fruits per plant was increased with increase in drip irrigation levels and fertilizer levels, during both the experiments. In both fields alternate day drip irrigation treatments yielded lesser number of fruits compared to daily drip irrigation treatments. The lowest number of fruits was recorded in the treatment which received alternate day drip irrigation along with manual fertilizer application was given by Abdul Hakkim (2014).

Veeranna et al., (2001) reported that 80 per cent water soluble fertilizer (WSF) was effective in producing about 31 and 24.7 per cent higher chilli fruit yield over soil application of normal fertilizers at 100 per cent recommended level in furrow and drip irrigation methods, respectively, with 20 per cent of saving in fertilizers. Roy et al., (2011) showed in capsicum that the length and width of fruit and number of fruits per plant increased significantly with increasing nitrogen doses up to $100 \mathrm{~kg} \mathrm{~N} / \mathrm{ha}$. However, average weight of fruit increased significantly with increasing levels of $P$ up to $150 \mathrm{~kg} \mathrm{~N} / \mathrm{ha}$. Average weight of fruit and yield increased significantly with increasing levels of $\mathrm{P}$ up to the treatment $30 \mathrm{~kg} \mathrm{P} / \mathrm{ha}$, whereas length of fruit and number of fruits per plant was increased significantly up to the $60 \mathrm{~kg} \mathrm{P} / \mathrm{ha}$. Considering the combined effect of nitrogen and phosphorus, the maximum yield was 
recorded in the treatment combination of 150 $\mathrm{kg} \mathrm{N}$ and $30 \mathrm{~kg} \mathrm{P} / \mathrm{ha}$. Fertigation using water soluble fertilizers increased marketable yield in capsicum by 15.1 as compared to conventional application of fertilizers. The fertigation schedule was developed for protected conditions and 4.6 B.C ratio was obtained with capsicum.

\section{Onion}

Chopade et al., (1998) found that drip irrigation with the recommended rate of solid fertilizer in two applications gave the highest onion bulb yield while drip fertigation at 50 per cent of the recommended rate gave the highest bulb quality. Rumpel et al., (2004) obtained higher marketable onion yields when the $50 \mathrm{~kg} / \mathrm{ha} \mathrm{N}$ rate was applied through drip fertigation (41 per cent increase) and highest after applying $150 \mathrm{~kg} \mathrm{ha}{ }^{-1} \mathrm{~N}$ through fertigation (79 per cent increase) as compared to the control (without fertigation and irrigation). Dingre et al., (2012) showed that drip fertigation resulted into 12 to 74 per cent increase in the productivity of onion seed as compared to conventional method. The total irrigation water applied through surface and drip system was $840 \mathrm{~mm}$ and $520.45 \mathrm{~mm}$ indicating 39 per cent water saving whereas, field water use efficiency of drip fertigation was more by 2.5 times as that of control. Rajput and Patel (2006) recorded the highest onion yield in daily fertigation followed by alternate day fertigation.

Lowest yield was recorded in monthly fertigation frequency. Bhakare and Fatkal (2008) showed that the onion seed yield increased and yield contributing characters improved with fertigation levels with maximum in 125 per cent recommended dose of fertilizer (RDF) fertigation treatment which was at par with 100 per cent RDF fertigation treatment. The treatment 75 per cent RDF through fertigation was significantly superior to application of $100 \%$ RDF through conventional fertilizer and as such, there could be a saving of 25 per cent of the added fertilizer.

Bhakare and Fatkal (2008) was stated that application of 125 per cent recommended dose of water soluble fertilizer with fertigation gave the highest yield of onion seed and improved the yield contributing parameters such as plant height, number of umbels per plot, number of umbels per plant, diameter of umbel and reduced the time to $50 \%$ flowering, but the yield was at par with 100 per cent recommended dose of water soluble fertilizers with fertigation.

\section{Garlic}

Garlic crop grown under furrow irrigation took up $64 \mathrm{~kg} \mathrm{P}_{2} \mathrm{O}_{5} / \mathrm{ha}$, while under fertigation the crop took up $89 \mathrm{~kg} \mathrm{P}_{2} \mathrm{O}_{5} / \mathrm{ha}$ was given by Castellanos et al., (2001). The respective crop yields were 19.1 and 29 t/ha. Thus, higher yield potential of the crop under fertigation increased $\mathrm{P}$ demand of plants by almost 50 per cent. Highest yield of 36.29 t/ha of fresh tubers was obtained under trickle irrigation as compared to $21.5 \mathrm{t} / \mathrm{ha}$ for the furrow irrigated crop was reported by Chawla and Narda (2001).

\section{Cucumber}

Ibrikci and Buyuk (2002) obtained higher yield and leaf $\mathrm{N}, \mathrm{P}$ and $\mathrm{K}$ content in drip fertigated cucumber than furrow irrigated plants. Beyaert et al., (2007) showed that drip irrigation coupled with fertigation showed significant advantages in terms of yield and economic returns of cucumber compared with overhead irrigation and conventional fertilization practices. The fertigation schedule was developed for protected conditions and 3.3 B.C ratio was obtained with cucumber. 
Table.1 Fertiliser use efficiency (\%) in fertigation

\begin{tabular}{|c|c|c|c|c|}
\hline S.No & Nutrient & Soil application & Drip + soil application & Drip + fertigation \\
\hline 1. & $\mathrm{~N}$ & $30-50$ & 65 & 95 \\
\hline 2. & $\mathrm{P}_{2} \mathrm{O}_{5}$ & 20 & 30 & 45 \\
\hline 3. & $\mathrm{~K}_{2} \mathrm{O}$ & 60 & 60 & 80 \\
\hline
\end{tabular}

Fertiliser Marketing News, 2010

Table.2 Fertilizers commonly used in fertigation

\begin{tabular}{lcc}
\hline \multicolumn{1}{c}{ Name } & $\mathbf{N}-\mathbf{P}_{\mathbf{2}} \mathbf{O}_{\mathbf{5}}-\mathbf{K}_{\mathbf{2}} \mathbf{O}$ content & Solubility $\mathbf{( g / l )}$ at $\mathbf{2 0}^{\mathbf{0}} \mathbf{C}$ \\
\hline Ammonium nitrate & $34-0-0$ & 1830 \\
Ammonium sulphate & $21-0-0$ & 760 \\
Urea & $46-0-0$ & 1100 \\
Monoammonium phosphate & $12-61-0$ & 282 \\
Diammonium phosphate & $18-46-0$ & 575 \\
Potassium chloride & $0-0-60$ & 347 \\
Potassium nitrate & $13-0-44$ & 316 \\
Potassium sulphate & $0-0-50$ & 110 \\
Monopotassium phosphate & $0-52-34$ & 230 \\
Phosphoric acid & $0-52-0$ & 457 \\
\hline
\end{tabular}

Table.3 Water soluble fertilizers

\begin{tabular}{lccc}
\hline Name of WSF & $\mathbf{N} \%$ & $\mathbf{P}_{\mathbf{2}} \mathbf{O}_{\mathbf{5}} \mathbf{\%}$ & $\mathbf{K}_{\mathbf{2}} \mathbf{O} \%$ \\
\hline Polyfeed & 19 & 19 & 19 \\
Polyfeed & 20 & 20 & 20 \\
Polyfeed & 11 & 42 & 11 \\
Polyfeed & 16 & 8 & 24 \\
Polyfeed & 19 & 19 & 19 \\
Polyfeed & 15 & 15 & 30 \\
MAP & 12 & 61 & 0 \\
Multi-K & 13 & 0 & 46 \\
MKP & 0 & 52 & 34 \\
SOP & 0 & 0 & 50 \\
\hline
\end{tabular}

\section{Okra}

The available literature provides sufficient evidence in favour of increased productivity of vegetable crops due to fertigation. The yield of okra under conventional method of fertilization with 100 per cent of recommended dose of fertilizers and under fertigation with 60 per cent of recommended dose of fertilizers was not significantly different $(23.0 \mathrm{t} / \mathrm{ha}$ and $23.1 \mathrm{t} / \mathrm{ha}$ in the year 2000 and $23.56 \mathrm{t} / \mathrm{ha}$ and $23.35 \mathrm{t} / \mathrm{ha}$ in the year 2001) was given by Patel and Rajput (2004). This indicates that a saving of 40 per cent in fertilizer use may be achieved if applied through fertigation without affecting the okra yields. More than 16 per cent increase in yield under fertigation (25.21 per cent in the year 2000 and 16.59 per cent in the year 2001) was observed as compared broadcasting method of 
fertilizer application when 100 per cent recommended dose of fertilizers was applied. Similar results of increase in productivity of chilli crop due to fertigation were reported by Veeranna et al., (2001).

Rajput and Patel (2002) at Water Technology Centre, New Delhi conducted a fertigation trial in bhendi with 40, 60, 80 and 100 per cent RDN through drip and 100 per cent RDN by broadcasting with furrow irrigation, the results of the study revealed that drip fertigation was superior over broadcasting in terms of enhancing yield attributes and yield.

Application of 60 per cent RDN through drip fertigation recorded comparable pod yield with that of 80 and 100 per cent RDN, which indicates a saving of nitrogen to the tune of 40 per cent. Satpute et al., (1992) reported that drip fertigation with 100 per cent nitrogen recorded maximum number of pods per plant (21), pod yield per plant (129.3 g) and yield $\left(17.3 \mathrm{t} \mathrm{ha}^{-1}\right)$ over furrow irrigation + band placement of 100 per cent N. Similarly, fertigation of 75 per cent RDN through subsurface biwall drip system recorded higher pods per plant, pod weight and pod yield over 100 per cent RDN applied by band placement + furrow irrigation, indicates saving 25 per cent nitrogen (Chaudhari et al., 1995). Rekha and Mahavishnan (2008) reported the water and fertilizer saving by 40-70 and 30-50 per cent, respectively through drip fertigation in Okra.

\section{Sweet pepper}

Kaushal et al., (2012) reported that the drip irrigation adoption increased water use efficiency (60- 200 per cent), saved water (20-60 per cent), reduced fertilization requirement (20-33 per cent) through fertigation, produced better quality crop and increased yield (7-25 per cent) as compared with conventional irrigation.

\section{Celery}

Kaniszewski et al., (1999) reported that fertigated celeriac plants had greater leaf area, dry matter production and nitrate $\mathrm{N}$ and total $\mathrm{N}$ contents than those given through broadcast $\mathrm{N}$ with or without drip irrigation.

\section{Pea}

Singh et al., (2006) showed that the increase in $\mathrm{N}$ through fertigation caused increased in green pea yield at all the levels of drip irrigation (0.5 Epan, 0.75 Epan and 1.0 Epan), but the magnitude of increase was highest at lowest level of water supply.

\section{Fertigation and resource use efficiency}

Water and fertilizer are the two important inputs for agricultural production and are interrelated in their effect on plant growth and yield. Since, water and fertilizer are costly inputs; every effort must be made to enhance water and fertilizer use efficiency by reducing their wastage. In recent years fertigation a technique of application of both water and fertilizers via an irrigation system was shown to be very effective in achieving higher water and fertilizer use efficiency. In this method both water and fertilizer are delivered precisely in the crop root zone as per the crop needs and according to crop developmental phase. Increased growth and yield with drip irrigation has been reported in several crops and the increase in yield ranged between 7 112 per cent depending on the crops/varieties and method of irrigation compared. The water and fertilizer saving through drip fertigation have been reported to be $40-70$ and $30-50$ per cent, respectively.

The fertigation allows application of right quantity of nutrients uniformly to the wetted root volume, where the active roots are concentrated and this helps enhance fertilizer 
use efficiency. This in turn allows reducing the amount of fertilizer to be applied and ultimately the production costs. Stark et al., (1983) used continuous fertigation of surface drip irrigated tomato on sandy soils and they reported NUE of 60 per cent even at $600 \mathrm{~kg}$ N/ha application. Bhakare and Fatkal (2008) observed highest FUE when 50 per cent RDF was applied through drip irrigation. They found lowest FUE when 100 per cent RDF was applied through conventional fertilizer application method and irrigation water was applied by surface application. FUE was significantly higher in 100 per cent NPK fertigation (138 kg yield/kg NPK) compared to furrow irrigation (81), drip irrigation (103), 50 per cent NPK fertigation (114) and 75 per cent NPK fertigation (127) in tomato (Shedeed et al., 2009). This was due to better availability of moisture and nutrients throughout the growth stages in drip and fertigation system leading to better uptake of nutrients and production of tomato fruits. Fertigation saves fertilizer nutrients as it permits applying fertilizer in small quantity at a time matching with the plants nutrient need thus, leading to higher NUE (Veeranna et al., 2001). Frequent supply of nutrients with irrigation water in fertigation treatments significantly increased NPK uptake and recovery over drip and furrow irrigation (Shedeed et al., 2009). The applied NPK in soluble form in fertigation treatments may have been distributed better through root zone of tomato than soil applied treatments, thus producing more available amounts for plant uptake.

Bhakare and Fatkal (2008) reported 40\% saving of water due to fertigation over conventional fertilizer application and surface irrigation. They also recorded WUE of 2.37 $\mathrm{kg} / \mathrm{ha}-\mathrm{mm}$ with 125 per cent RDF applied through water soluble fertilizers with drip irrigation compared to $0.90 \mathrm{~kg} / \mathrm{ha}-\mathrm{mm}$ with 100 per cent RDF through conventional fertilizers + surface irrigation. Singh et al., (2002) reported 41 and 51 per cent saving in water and 187.69 and 123.14 per cent increase in WUE due to fertigation in broccoli and radish, respectively over check basin method of irrigation. Similarly, drip irrigation at 50 per cent $\mathrm{PE}+100$ per cent $\mathrm{N}$ and $\mathrm{K}$ through fertigation recorded highest water use efficiency, water productivity and water saving in chilli over farmers practice of surface irrigation (0.9 IW/CPE ratio) + entire NPK as soil application. Water and fertilizer savings to the extent of 30 and 70 per cent, respectively with comparable yield levels was possible under the trickle fertigated crop as compared to the furrow irrigated crop of potato was given by Chawla and Narda, 2001). Higher WUE and water saving has been reported by other workers also (Shedeed et al., 2009; Rhoads et al., 1996; Singandhupe et al., 2003).

Singandhupe et al., (2003) reported that there was 3.7-12.5 per cent higher fruit yield with $31-37 \%$ saving of water while using drip system in tomato crop when compared to surface irrigation. Water use efficiency in drip irrigation, on an average was 68 per cent and 77 per cent higher over surface irrigation in two consecutive year trials. Aujla et al., (2007) reported that 50 per cent water saving could be achieved through drip irrigation in brinjal while obtaining 4 per cent yield increase as compared to furrow irrigation.

Drip irrigation with fertigation in brinjal gave superior fruit yield and saved 37-49 per cent water when compared to surface irrigation Goswami et al., (2006). Sivanappan (1979) gave similar findings in brinjal, tomato and chilli. Singandhupe et al., (2003) reported that application of nitrogen through the drip in ten equal splits at 8-days interval saved $20-40$ per cent nitrogen as compared to the furrow irrigation and nitrogen application in two equal splits (as in conventional method). The 
water and fertilizer saving in vegetables through drip fertigation is around 40-70 per cent and 30-50 per cent, respectively (Rekha and Mahavishnan, 2008).

\section{Benefits of fertigation}

\section{Higher nutrient use efficiency}

Nutrient use efficiency by crops is greater under fertigation compared that under conventional application of fertilizers to the soil.

\section{Less water pollution}

Intensification of agriculture led by use of irrigation water and indiscriminate use of fertilizers has led to the pollution of surface and ground water by chemical nutrients.

Fertigation helps lesser pollution of water bodies through the leaching of nutrients such as $\mathrm{N}$ and $\mathrm{K}$ out of agricultural fields.

\section{Higher resource conservation}

Fertigation helps in saving of water, nutrients, energy, labor and time.

\section{More flexibility in farm operations}

Fertigation provides flexibility in field operations e.g. nutrients can be applied to the soil when crop or soil conditions would otherwise prohibit entry into the field with conventional equipment.

\section{Efficient delivery of micronutrients}

Fertigation provides opportunity for efficient use of compound and ready-mix nutrient solutions containing small concentrations of micronutrients, which are otherwise very difficult to apply accurately to the soil when applied alone.

\section{Healthy crop growth}

When fertigation is applied through the drip irrigation system, crop foliage can be kept dry thus avoiding leaf burn and delaying the development of plant pathogens.

\section{Helps in effective weed management}

Fertigation helps to reduce weed menace particularly between the crop rows. Use of plastic mulch along with fertigation through drip system allows effective weed control in widely spaced crops.

\section{Effective use of undulating soils}

The ability of micro irrigation system to irrigate undulating soils makes it possible to bring such land under cultivation, which otherwise remain as wastelands or used as pasturelands.

\section{Reduced soil compaction}

In micro irrigation system reduced need for surface traffic movement during irrigation and nutrient application helps to reduce soil compaction.

\section{Effective use of undulating soils}

The ability of micro irrigation system to irrigate undulating soils makes it possible to bring such land under cultivation, which otherwise remain as wastelands or used as pasturelands.

\section{Reduced soil compaction}

In micro irrigation system reduced need for surface traffic movement during irrigation and nutrient application helps to reduce soil compaction. Fertigation provides a variety of benefits to the users like high crop productivity and quality, resource use 
efficiency, environmental safety, flexibility in field operations, effective weed management and successful crop cultivation on fields with undulating topography. In conclusion, fertigation system is efficient method applying fertilizers in which the irrigation system is used as the carrier and distributor of the crop nutrients. The combination of water and nutrient leads to an efficient use of both by the plant. The use of solid fully soluble fertilizers seems more economical in the first stages when fertigation is adopted, but the use of prepared clear liquid solutions is very convenient in other cases. The fertigation system is very suitable for commercial agriculture for maximize profit and yield. Fertigation has been found as one of most successful way of water and nutrient particularly $\mathrm{N}, \mathrm{K}$ and micronutrient application through drip system. This helps in increasing the production. Fertiliser application through drip system (fertigation) helps in proper utilization of fertilizers, saves labour and increases the productivity. Yield advantages have been reported across the wide range of crops under diverse agroclimatic situations. Vegetables have been found particularly responsive to fertigation due to their wide spacing nature, continuous need of water and nutrients at optimal rate to give high yield with good quality, high capital turn over to investments and may be their cultivation by more skilled farmers. Eventhough the initial cost of establishing the fertigation system is higher but in long term basis it is economical compared to conventional methods of fertilization as it brings down the cost of cultivation. However, to get the desired results it requires higher management skills at operator level like selection of fertilizers, timing and rate of fertilizer injection, watering schedule, as well as the maintenance of the system. Therefore, to make the agriculture sustainable and economically viable and to ensure food and nutritional security of the burgeoning population there is need to promote the fertigation at large scale by the concerned stakeholders.

\section{References}

Abdul Hakkim. 2014. Effect of Site Specific Drip Fertigation on Yield of Chilli. IOSR Journal of Engineering (IOSRJEN). 4(1): 33-44.

Aujla, M.S., H.S. Thind and G.S. Buttar. 2007. Fruit yield and water use efficiency of eggplant as influenced by different quantities of nitrogen and water applied through drip and furrow irrigation. Scientia Horticulturae. 112: 142-148.

Bafna, A.M., S.Y. Daftardar, K.K. Khade, V.V. Patel, R.S. Dhotre. 1993. J. Water Manage., 1 (1):1-5.

Bansod, R.D. 2007. Evaluation of cauliflower under furrow and micro sprinkler irrigation. Asian J. Soil Sci., 2(1): 6567.

Beyaert, R.P, R.C. Roy and B.B.R. Coelho. 2007. Irrigation and fertilizer management effects on processing cucumber productivity and water use eddiciency. Canadian J Plant Sci., 87: 355-363.

Bhakare, B.D and Y.D. Fatkal. 2008. Influence of micro irrigation and fertilizer levels on growth yield and quality of onion seed. J. water Mangnt., 16(1): 35-39.

Bozkurk, S., V.Uygur, N. Agca and M.Yalcin. 2011. Yield responses of cauliflower (Brassica oleracea var. botrytis. L.) to different water and nitrogen levels in a Mediterranean Coastal area. Acta. Agric. Scand., 61(2): 183-194.

Bucks, D.A. and F.S. Nakayama. 1980. In: Proc. Agri-Turi. Irrig. ConI., California, pp 166-180.

Castellanos, J.Z., Ojodeagua, J.L., Mendez, 
F., Villalobos-Reyes, S., Badillo, V., Vargas, P. and Lazcano-Ferrat, I. 2001. Better Crops International. 15 (2): 21 23.

Chawla, J.K. and N.K. Narda. 2001. Irrigation and Drainage. 50 (2):129-137.

Chetan, S. and K.G. Singh. 2009. Production function for irrigation water and nitrogen requirements of early cauliflower in greenhouse. J. Agric. Eng., 46(1): 60-64.

Chetan, S. and K.G. Singh. 2011. Crop water requirements and fertigation options for early drip irrigated cauliflower (Brassica oleracea var. botrytis Linn.) grown in a greenhouse. Prog. Horticul., 43(1): 99-101.

Chopade, S.O., P.N. Bansode, S.S. Hiwase and R.C. Bhuyar. 1998. Effect of drip fertigation on physiological growth of onion. Annals Plant Physio., 11: 45-48.

Darwish, T., T. Atallah, S. Hajhasan and A. Chranek. 2003. Nutr Cycl in Agroecosyst. 67(1): 1-11.

Dingre, S.K, D.D. Pawar and K.G. Kadam. 2012. Productivity water use and quality of onion (Allium cepa) seed production under different irrigation scheduling through drip. Indian J Agron., 57: 186190.

Gornat, B., D. Goldberg, D. Rimon and J. Asher Ben. 1973. J. Am. Soc. Horti. Sci., 98 (2): 202-205.

Goswami, S.B., S. Sarkar and S. Mallick. 2006. Crop growth and fruiting characteristics of Brinjal as influenced by gravity drip. Indian Journal of Plant Physiology. 11: 190-194.

Hartz, and T.G. Bottoms 2009. Nitrogen requirements of drip irrigated processing tomatoes. Hort Science. 44: 1988-1993.

Haynes, R.J. (1985). Fert. Res., 6: 235-255.

Hebbar, S.S., B.K. Ramachandrappa, H.V. Nanjappa and M. Prabhakar. 2004. Studies on NPK drip fertigation in field grown tomato (Lycopersicon esculentum Mill.). European Journal of Agronomy. 21:117-127.

Ibrikci, G.S and H.Buyuk 2002. Yield and elemental composition of cucumber as affected by drip and furrow irrigation. Acta Hort., Pp.51-57.

Imtiyaz, M., A. Rongmei and V. Singh. 2009. Optimum irrigation scheduling of cabbage. Proceeding of the $10^{\text {th }}$ International Agricultural Engineering Conference held in Bangkok (Thailand) during $7-10^{\text {th }}$ December, 2009. Role of agricultural engineering in advent of changing global landscape; unpaginated.

Jat, R.A., S.P. Wani Sahrawat, K.L.S. Piara and B.L. Dhaka. 2011. Fertigation in Vegetable Crops for Higher Productivity and Resource Use Efficiency. Indian Journal of Fertilizer. 7 (3): 22-37.

Kaniszewski, S, J. Rumpel and J. Dysko 1999. Effect of drip irrigation and fertigation on growth and yield of celeriac (Apium graveolens L.var. rapaceum (Mill.) Gaud). Veg Crops Res Bulletin. 50: 31-39.

Kapoor, R. S.K. Sandal, K. Sharma Sanjay, Kumar and Saroch. 2014. Effect of varying drip irrigation levels and NPK fertigation on soil water dynamics, productivity and water use efficiency of cauliflower (Brassica oleracea var. Botrytis) in wet temperate zone of Himachal Pradesh. Indian J Soil Cons., 42: 249-254.

Kaushal, A., A.S. Lodhi and K.G. Singh 2011. Economics of growing sweet pepper under low tunnels. Prog Agri., 67-72.

Kumar, A and A.K. Singh. 2002. Improving nutrient and water use efficiency through fertigation. J Water Mangnt., 10: $42-48$.

Manfrinato, H.A. 1971. Effect of drip 
irrigation on soil water plant relationship. Second International Drip Irrigation Congress, Pp. 446-451.

Marouelli, W.A, O.A. Carrijo, R.B. Souza and W.L.C. Silva. 2011a. Irrigacao e fertirrigacaona cultura do tomate. In: Sousa VF, Marouelli WA, Coelho EF, Pinto JM, Coelho Filho M. Irrigacao e fertirrigacaoem fruteiras e hortalicas. Brasilia. Embrapa Informacao Tecnologica. P. 739-769.

Marouelli, WA., M.A. Medeiros, F.V. Souzarf, Resende. 2011b. Producao de tomaterio organic irrigado por aspersao e gotejamento, em cultivo solteiro e consorciado com coentro. Horticultura Brasileira. 29: 429-434.

Marr, C.W. 1993. Commercial vegetable production, fertigation of vegetable crops. MF-1092. Kansas State University Agricultural Experiment Station and Cooperative Extension Services, Manhattan, KS.

Muralikrishnasamy, S., Veerabadran, V., Krishnasamy, S., Kumar, V., and Sakthivel, S. 2006. Drip irrigation and fertigation in chillies (capsicum annuum). $7^{\text {th }}$ International Micro Irrigation Congress.

Papadopoulos, I. and M. Ristimäki Leena, Nitrogen and phosphorus fertigation of tomato and eggplant. In: ISHS Acta Horticulturae 511: XXV International Horticultural Congress, Part 1: Culture Techniques with Special Emphasis on Environmental Implications - Nutrient Management (2000). Accessed at http://www.actahort.org/books/511/inde x.htm, dated 09/10/2010.

Patel, N. and Rajput, T.B.S. IE (I) Journal. AG, Vol 85, pp. 50-54 (2004).

Prabhakar, M. and S.S. Hebbar. 1996. Performance of some solanaceous and cucurbitaceous vegetables under micro irrigation system. All India Seminar on Micro irrigation Techiniques,
Bangalore, pp 74-77.

Rajput, T.B.S. and N. Patel. 2002. Ann.Agric. Res., 23: 164-165.

Rajput, T.B.S. and N. Patel. 2006. Water and nitrate movement in drip irrigated onion under fertigation and irrigation treatments. Agric. Water Mangnt., 79: 293-311.

Rekha, K.B. and K. Mahavishnan, 2008. Drip fertigation in vegetable crops with emphasis on lady's finger (Abelmoschus esculentus (L.) Moench) - A review. Agricultural Review. 29: 298-305.

Rhoads, F.M., S.M. Olson, G.J. Hochmuth and E.A. Hanlon, 1996. Yield and petiole-sap nitrate levels of tomato with $\mathrm{N}$ rates applied preplant or fertigated. Soil Crop Sci. Soc. Fla. Proc. 55:9-12.

Rolston, D.E. et al., (1979). Univ. Calif. Bul1., 1893: 1-14.

Roy, S.S, M.S.I. Khan and K.K. Pall. 2011. Nitrogen and phosphorus efficiency on the fruit size of capsicum. J. Expt Sci., 2: 32-37.

Rupel, J., S. Kaniszewski, and J. Dysko. 2004. Effect of drip irrigation and fertilization timing and rate on yield of onion. J. Veg Crop Production. 9: 6573.

Selim, E. and A.A. Mosa. 2012. Fertigation of humic substances improves yield and quality of broccoli and nutrient retention in a sandy soil. Journal of Plant Nutrition and Soil Science. 175(2): 273-281.

Shedeed, S.I., S.M. Zaghloul and A.A. Yassen. 2009. Effect of method and rate of fertilizer application under drip irrigation on yield and nutrient uptake by tomato. Ozean J Applied Sci., 2: 139-147.

Shinde, P.P., M.G. Chavan and V.B. Newase. 2006. Fertigation in cabbage. J. Maharashtra Agric. Uni., 3(3): 255-257.

Shirgure, P.S., A.K. Srivastava and Shyarn Singh. 2000. Water management in 
citrus - A Review. Agric. Rev., 21(4) 223-230.

Singandhupe, R.B, B.K. James, A. Edna and P. Nanda. 2007. Response of drip irrigation and mulching on growth and fruit yield of pointed gourd (Trichosanthes dioica). Indian J Agri Sci., 77: 8-13

Singandhupe, R.B., G.G. Rao, N.G. Patil and P.S. Brahmanand 2003. Europ. J. Agron., 19: 327-340.

Singandhupe, R.B., G.G.S.N. Rao, N.G. Patil and P.B. Brahmanand. 2003. Fertigation studies and irrigation scheduling in drip irrigation system in tomato crop (Lycopersicon esculentum L.) Europ. J. Agron. 19: 1-17.

Singh, A.K., D. Chakraborty, P. Mishra and D.K. Singh. 2002. Nitrogen and potassium dynamics in fertigation systems. In $17^{\text {th }}$ WCSS, Thailand, 14-21 August, 1045: 1-10.

Singh, K.G., M. Siag, and G. Hajan. 2006. Water and nutrient requirement of drip irrigated green pea. Harayana J. Hort Sci., 35: 320-322.

Sivanappan, R.K. 1979. Sprinkler and drip irrigation. Indian Farming. 27: 23-24.

Tu, J.C., A. Liptay, C.S. Tan, C.F. Drury and D. Reynolds, Effect of drip irrigation and drip fertigation on yield of processing tomato in south-western Ontario. ISHS Acta Horticulturae 635: XXVI International Horticultural Congress: Managing Soil-Borne Pathogens: A Sound Rhizosphere to Improve Productivity in Intensive Horticultural Systems (2000). Accessed at http://www.actahort.org/books/511/ index.htm, dated 09/10/2010.

Vaishnava, V.G., G.S. Jadhav, D.G. Shelke, P.R. Bharmbe and S.R. Oza. 1995. Optimization of irrigation water and nitrogen.

Veeranna, H.K, A.A. Kgalak Abduk, G.M. Sujith. 2001. Effect of fertigation with normal and water soluble fertilizer compared to drip and furrow methods on yields, fertilizer and irrigation water use efficiency in chilli. Micro Irrigation. Pp.461-466.

Veeranna, H.K, Khalak Abdul, A.A. Farooqui and G.M. Sujith. 2001. Effect of Fertigation with Normal and Watersoluble Fertilizers Compared to Drip and Furrow Methods on Yield Fertilizer and Irrigation Water Use Efficiency in Chilli. Micro Irrigation, CBIP Publication, no 282, p. 461.

Vijayakumar, G., D.Tamilmani and P.K. Selvaraj. 2010. Irrigation and Fertigation Scheduling under drip Irrigation in Brinjal crop. Indian Journal of Bioresource Management. 1: 72-76.

Yadav, B.S., G.R. Singh, J.L. Mangal and V.K. Srivastava. 1993. Drip irrigation in vegetable production. Agric. Res. (Karnal) J. 14(2): 75-82.

Zhang, T.Q., C.S. Tan, K. Liu, C.F. Drury, A.P Papadopoulos and J. Warner 2010. Yield and economic assessments of fertilizer nitrogen and phosphorus for processing tomato with drip fertgation. Agronomy Journal. 102: 774-780.

\section{How to cite this article:}

Sathya Priya, R., C. Chinnusamy, R. Karthikeyan and Kuttimani, R. 2017. Drip Fertigation in Vegetable Crops for Enhancing Productivity and Resource Use Efficiency: An Overview. Int.J.Curr.Microbiol.App.Sci. 6(11): 3215-3230. doi: https://doi.org/10.20546/ijcmas.2017.611.377 